\title{
Research on Influencing Factors of Personalized Service on Brand Equity in New Retail Formats
}

\author{
Hongfei Sun Fangyu Liu Yiming Jiang Shiqi Shen \\ School of Economics and Management Northeast Dianli University Jilin China 132012
}

\begin{abstract}
In recent years, with the rapid development of the Internet and big data, a single online physical retail and a single offline electronic retail can no longer adapt to the " $5 \mathrm{G}$ big data "background. The new retail model of online and offline combination has become a major trend in the industry. With the improvement of national income level," price competition "is no longer the survival law of retail trade. People pay more and more attention to the quality of life, so how will the new retail development in the future, and what will its survival law become? Through the analysis of most scholars, brand assets play an important role in online channels. This paper will explore the influence mechanism of personalized service on brand equity under the new retail format from the perspective of user cognition and put forward the countermeasures for the future appreciation of brand equity. It enriches the theoretical system of related researches and helps realize a new breakthrough for new retail enterprises.
\end{abstract}

Keywords: brand equity; personalized service; new retail format

Fund project: 1 The "13th Five-Year" Scientific Research Planning Project of the Education Department of Jilin Province (Social Science Research Project) "Research on Multi-Source Fusion Personalized MicroReading User Portrait Model Based on User Cognition" (JJKH20190715SK).

2 The General Project of Higher Education Scientific Research of Jilin Provincial Higher Education Association "Research on Influencing Factors and Promotion Strategies of Online Classroom Teaching in Colleges and Universities" (JGJX2020D93).

3 The "13th Five-Year" Scientific Research Planning Project of the Education Department of Jilin Province (Social Science Research Project) "Research on the Construction Model and Influence Improvement Path of Jilin Province's New Type of University Think Tanks" (JJKH20180459SK).

DOI : 10.36012 /ems. v2i2. 2794

\section{Introduction}

\section{1 Practice Background}

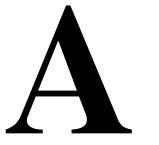

$\mathrm{t}$ present, the operating profits of traditional domestic physical stores and single online shops have continued to decline in recent years, many physical stores have also closed down, and some enterprises have tried to innovate and change in order to get rid of difficulties. But it still hasn't done much. In the new retail era, the online sales of retail enterprises are increasing, and there are more and more offline stores. The unsuccessful integration of online and offline information asymmetry is a major bottleneck in the current development of retail enterprises in China.

With the rapid development of China's economic level and the explosive growth of big data, consumers' living standards are getting higher and 
higher. Consumers are no longer satisfied with the necessary life requirements but pay more attention to the quality of life and self-demand. Therefore, the development of personalized services is also imminent.

\section{2 Theoretical Background}

At present, the research on personalized service based on the Internet environment is rich at home and abroad, including the concept, characteristics, composition dimension, technology application, etc. At the same time, there are many research results on new retailing, including the concept, characteristics, and classification of new retailing, which lays a foundation for the research of personalized service under the environment of new retail format.

By comparing objective data, it is found that the market share of new retail enterprises with personalized services to meet the needs of users is much higher than that of new retail enterprises limited to standardized services. Based on the new retail situation, this paper studies the component dimension of personalized service and its influence mechanism on brand assets.

\section{3 Issues Raised}

The research of personalized service mostly stays in the computer field, and the joint research with a retail field is still few at home and abroad. However, at present, the cost of obtaining customers is getting higher and higher, but the customers are not very satisfied with the services provided by the merchants. The main reason is that the services provided by the merchants are uniform and do not understand the pain points of the consumers.

Under this background condition, it is urgent to explore the personalized service under the new retail format, so what kind of influence will the personalized service under the new retail format bring to the brand assets of the enterprise?

\section{Research on the Influence of Personalized Service on Brand Assets}

\section{1 Influence Mechanism of Personalized Service on Brand Asset Elements}

The elements of new retail, personalized service, and brand assets all have overlap points "peopleoriented" in the current background, and their purpose is also to meet the different needs of users, to break through the bottleneck through per- sonalized services, to pursue differentiated competition, and to accumulate brand assets through personalization. Realize brand asset premium.

According to the characteristics and present situation of new retail, the dimension of personalized service in retail format is based on the index system of satisfying the personalized service quality elements on the three nodes of online, offline, and intelligent logistics under the background of the Internet and big data.

\section{2 Mediating effect of brand trust}

Brand trust is important at every stage of the new retail service. Research by Shen Pengyi and Fan Xiucheng found that customers experience a pleasant attitude and emotional response to retail websites after contacting them. The empirical study of Wang Xuhui and Zhang Qilin shows that the higher the information quality of user- generated content, the higher the trust of consumers in offline and online stores and the higher the brand equity is driven by the information quality factors of personalized service, which directly proves the positive relationship between brand trust and brand equity of retailers.

Within the context of the new Internet, the relationship between personalized service and brand trust under the online retail node has been proved by many scholars in the academic circle. Therefore, it can reflect the mediating effect of brand trust.

\section{3 The mediating effect of brand loyalty}

There are many factors that influence online brand loyalty. Srinivasan found through empirical analysis that customization, contact and interaction, cultivation, care, virtual community, selectivity, and website characteristics all have positive effects on online brand loyalty. Through study, Deng Aimin et al. concluded that brand trust can become a direct anti-dilutive variable of brand loyalty, and can indirectly affect brand loyalty by influencing customer satisfaction degree, and finally affect brand equity. Website performance and logistics service quality also have a direct positive impact on brand loyalty through customer satisfaction degree, and finally indirectly affect brand equity.

Therefore, under the new retail situation, customer satisfaction is an important anti force of 
brand loyalty. Brand trust plays an intermediary role in the relationship between customer satisfaction and brand loyalty. Personalized service has a significant positive impact on brand loyalty.

\section{Countermeasure of Future Value - added of}

\section{Brand Assets}

Realize the profound fusion of line and line. The characteristics of products and services must meet the characteristics of new retailing. The requirements of products and services on each node of retail operation mode can meet users' needs and improve their satisfaction, perceived value, and quality. In the personalized service of the online and offline integration process, it is mainly suggested that enterprise managers improve the empathy, re $^{-}$ sponsiveness, and consistency of service quality, and then have a direct impact on brand trust, image, and loyalty, which makes brand assets increase.

Enhance the offline situational experience. Offline experience brings rich customer resources to enterprises at a low cost. On the one hand, offline experience increases consumer experience and entertainment; on the other hand, it increases the timeliness of service so that the users' current needs can be met in a timely manner. Increase user satisfaction, enhance brand image, trust and loyalty. Therefore, it is suggested that enterprise managers adapt to the changes of the data age, develop stores and decorate stores as much as possible so that shops can give users a "home comfort" and $100 \%$ instant service all the time. Provide the services they need when all users need them.

It is suggested that enterprise managers should open some intelligent logistics and intelligent resource sharing services to increase their understanding of users, thus directly affecting brand loyalty and enabling users to track items at any time. Smart sharing services would allow users to record their consumption in any store and online so that all information quality is guaranteed.

\section{Conclusion}

Based on the perspective of user cognition, this paper explores the influence of personalized service on brand equity and the mediating role of brand trust and brand loyalty under the new retail format and draws several conclusions and inspirations.

(1) This topic introduces the new retail format, personalized services, brand assets, and other related elements. The new retail format is a new retail model based on the Internet. Through advanced technology, such as big data, artificial intelligence, and based on the user's cognitive perspective, the online service and offline experience and modern logistics are deeply integrated. Personalized service is based on standardization and diversification through customer-oriented detail improvement to provide users with more services in line with the individual itself. Brand assets are the unity of brand name and logo, which can increase or reduce the value of products or services sold by enterprises.

(2) Today's society is a society based on information technology. User personalized service is an important part of brand promotion. Online and offline services are not only the source of brand promotion and its assets but also the center of user experience. User personalized service promotes the running mechanism of brand assets in time, space, content, and so on and runs through the whole consumption process in time, which becomes the inevitable choice of users.

(3) Personalization needs us to promote brand path diversification in space, brand promotion in content to cultivate online and offline users' personalized service pursuit. Brand equity premium must face the lingering background of the new retail format. User personalized service not only needs to reflect the requirements of the new retail format but also needs to lead the brand to face the globalization trend of the new retail format from this background.

\section{References}

[1] Kang Yilin. The Story of Brand Communication of E - commerce Enterprises under the Background of New Retail[J]. Journal of News Research, 2019,10 (5) : $42-43$.

[2] Luo Qian, Chen Junkun. Research on the Influencing Factors of Customer's Consumption Intention under the New Retail Format Based on the Perspective of Customer Experience[J]. Economic research guide, 2019 , 394 (8).

[3] Dong Changliang. Research on Innovation Path of Retail Enterprises' New Business Model under the Background of Consumption Upgrade $[\mathrm{J}]$. Journal of $\mathrm{Si}^{-}$ chuan Ordnance Industry, 2020, 014 (003): 61-72. 